\title{
Bionematicidal Potential of Some Incorporating Plants on Meloidogyne javanica Control on Tomato
}

\author{
R.A. Bakr* \\ Agricultural Botany Department, Faculty of Agriculture, Menoufia University, Egypt \\ *Corresponding author
}

\section{A B S T R A C T}

\begin{tabular}{|l|}
\hline Ke y w o r d s \\
$\begin{array}{l}\text { Tomato, Meloidogyne } \\
\text { javanica, Root-knot } \\
\text { nematodes, Control }\end{array}$ \\
\hline Article Info \\
\hline $\begin{array}{l}\text { Accepted: } \\
12 \text { April } 2018 \\
\text { Available Online: } \\
10 \text { May } 2018\end{array}$ \\
\hline
\end{tabular}

Experiments carried out to estimate the potential of incorporating garlic (Allium sativumm), onion (Allium cepa) and Lemon grass (Cymbopogon citratus) on root-knot nematode Meloidogyne javanica affecting tomato under glasshouse conditions and concentration at 1, 2 and $3 \%$ of each plant used. Plants un-inoculated by nematode keep as control in four replicates. Results elucidate that nematode population and tomato plant growth parameters affected by using the different plants. Observation of root system revealed that number of egg-masses, galls and females/root system affected markedly. The garlic at $3 \%$ give the highest reduction in nematodes parameters followed by onion $3 \%$ while the least one was Lemon grass at $1 \%$ comparing to untreated infected plants. Fresh root weight and shoot fresh and dry weights raise compared to control plants. Therefore, using these plants may provide a prime and importance method in the integrated nematode management (INM) practices as environmental safety and economical as anew alternative to originally chemical nematicides.

\section{Introduction}

In Egypt, Tomato (Lycopersicon esculentum L.) is a vegetable crop member of the family Solanaceae grown in wide areas in open fields or greenhouses all over the year according to climate conditions. Different soil biotic pathogens attacks tomato with different severity according to the cultivar, soil type, environmental condition in the present of the causal organism. Plant parasitic nematodes (PPN) put themselves as aninfamous destructive member of tomato plant pathogens worldwide. The estimated annual losses in tomato due to PPN in Egypt reached $12 \%$ in 2014 [1]. Root-knot nematodes, Meloidogyne consider one of the limiting factors for profitable tomato plantation [2, 3]. Infected plants appear yellowish, stunt developed to wilting and root galling. Those, uptake of water and nutrient elements affected which refer to decrease quality and productivity of tomato. Damage varying according to the cultivar, nematode species, soil type, level of soil infestation and environment [4]. As a global problem, the solution will be by any method, e.g. physical, chemical or biological control methods. Farmers usually using chemical nematicides as the maximum effective method rather than other approaches in controlling and for limiting the damage of PPN. Unfortunately, Indiscriminate use of this 
nematicides sometimes results in different dangerous ecological effects [5]. Awareness of nematologists about the harmful effects of nematicides and environmental consideration try to shift from the conventional use of chemicals to eco-friendly alternative control strategies [6]. Using of bionematicides from plant origin is from the most promising alternatives because they degrade tonontoxic products, less harmful to non-target organisms and environment friendly [7]. Plants from different families reported to showed nematicidal effect on plant parasitic nematodes [8]. Soil amendments with organic amendments using botanical materials not only safe but also improve soil structure, fertility and control of soil borne pathogens [9]. Moreover it reported to be effective in suppress PPN on different crops. Nematicidal effect of garlic, onion and Lemon grass reported against plant parasitic nematode in banana, eggplant and sugar beet [10, 11]. Therefore, the objective of this study was to evaluate the bionematicidal effect of some incorporating botanicals on root-knot M.javanica control in tomato plants.

\section{Materials and Methods}

\section{Collection and preparation of used plants.}

Garlic (Allium sativumm), onion (Allium cepa) and Lemon grass (Cymbopogon citratus) plants collected from the research farm, Faculty of Agriculture, Menoufia University, Egypt.

\section{Multiplication and preparation of root-knot nematodes inoculum}

Meloidogyne javanica were isolated and identification done according to [12] using perineal pattern technique. Single egg masses was used to inoculate black nightshade (Solanum nigrum) seedlings transplanting in plastic pots $30 \mathrm{~cm}$ in diameter filled with sterilized clay-sand soil $(1: 2 \mathrm{v} / \mathrm{v})$ and the pots maintained at $25 \pm 2{ }^{\circ} \mathrm{C}$ in the experimental glasshouse, Department of Agricultural Botany, Faculty of Agriculture, Menoufia University, Egypt. Two months after black nightshade infested with $M$. incognita. Plants uprooted and galled infested roots washed carefully with tap water. Roots cutting to short pieces then macerated for two periods of 10 seconds using a blender. Then macerated root placed in a bottle containing $0.5 \%$ of sodium hypochlorite $(\mathrm{NaOCl})$ [13]. Bottle vigorously shaken for 3 minutes to increase lysis gelatin matrix of egg masses consequence eggs releasing from the egg matrix. Solution then poured through sieves to remove the root tissue. Eggs collected on the $20 \mu \mathrm{m}$ sieve then washed several times with tap water to remove residual $\mathrm{NaOCl}$. Eggs then transferred to abeaker containing tap water. Number of eggs $/ \mathrm{ml}$ was counting under a stereomicroscope.

\section{Glasshouse experiment}

Complete fresh whole plants of garlic and onion and leaves of lemon grass mashed for small pieces and add at 1,2 and $3 \%$ to $30 \mathrm{~cm}$ dim pots filled with sterilized mixture of sand and clay soil (2:1, v/v). Three days later, one seedling tomato $\mathrm{cv}$. Beto 86 at 30 days old transplanted in the middle of the pots. Treated pots inoculated with $3000 M$. javanica eggs/pot made by pouring the aqueous solution into holes made around the seedlings in each pot. Non-inoculated pots served as control. Treatments replicated four times and coordinated in completely randomized block design under glass house conditions. Agricultural processing was done as needed. Two months after nematode inoculation, plant roots gently uprooted and washed using tap water. Fresh root and shoot weights recorded. Number of galls and egg masses /root system counted. Egg-masses counted after dipping in Phloxine-B stain solution at $0.015 \%$ for 20 
minutes [14]. Number of females /root system was counted using a stereomicroscope [15]. Number of second stage juveniles (J2S) /250g soil evaluated using the counting slide under a stereomicroscope according to Goody [16] using serial sieves and modified Baermann technique. Reduction Percentage in nematode parameters calculated according the following equation:

Reduction Percentage $=\frac{\text { Control }- \text { Treatment }}{\text { Control }} \times 100$

\section{Statistical analysis}

Data Statistical analysis using Duncan's Multiple Range test $(\mathrm{P}=0.05)$ using costat 6.3 version program.

\section{Results and Discussion}

Obtained data in table 1 clarified that garlic, onion and Lemon grass at the tested rates significantly $(\mathrm{p} \leq 0.05)$ reduced nematode parameters. However, there was variation among the treatments in reducing nematode parameters. The highest percentage of reduction in number of second stage juveniles in 250 gm soil $(69.90 \%)$ was obtained at the higher concentration of garlic followed by onion $(63.52 \%)$ compared with nematode alone. Results showed also that those treatments significantly $(\mathrm{p} \leq 0.05)$ decreased the number of galls/tomato root system. The treatment Garlic at 3\%recorded the highest reduction in number of galls/root system by $75.7 \%$ followed by $67.8 \%$ in onion compared with inoculated untreated plants. The same trend noticed by garlic at $3 \%$ in number of egg-masses and females/root system by 75.5 and $79.4 \%$ of reduction respectively. The lowest reduction in nematode parameters recorded with the treatment by lemon grass at $1 \%$ as it recorded 25.1, 49.4, 49.9 and $58.4 \%$ in number of J2S in soil, galls, egg-masses and females respectively compared with plants inoculated by nematode only (Fig.1 and 2).
Significant differences found between all treatments and nematode inoculated plants in all nematode related parameters but not found between all treatments each other. In general, the percentage of reductions positively correlated with used concentration, by increasing the treatment concentration the percentage of reduction increased.

The effect of treatments on tomato plant growth parameters i.e., plant height, root length, fresh root weight; fresh shoot weight and dry shoot weight after inoculation of plants with eggs of $M$. javanica is illustrated in table 2. Results showed that the treatments enhanced plant growth parameters compared with untreated inoculated plants.

The treatments did not result in significant differences in all the parameters. The highest increasing in plant height recorded with plants treated with garlic 3\% followed by onion 3\% and lemongrass $3 \%$ even there is no significance different between the each other while the significance different found with untreated inoculated plants and control. Similar trend recorded in root length, fresh root weight; fresh shoot weight. The lowest plant growth parameters observed in plants with nematode alone.

Applications of botanicals at all tested concentrations were significantly $(p<0.05)$ inhibited nematode related parameters and effective in controlling infestation of nematodes into tomato roots compared to untreated infected plants. In general, the mode of action of plant parasitic nematodes control by botanicals could be one or more of juvenile toxicant, anti-feedant, ovicidal properties, inducers of host resistance, growth disruption or repellent [17]. Earlier studies revealed that phytochemicals change nematode physiology by affecting: ion uptake, membrane permeability, enzymatic activity, cell division and electron transport [18]. 
Table.1 Effect of garlic, onion and lemon grass on mean number of galls, egg masses and females on tomato plants root system

\begin{tabular}{|c|c|c|c|c|}
\hline \multirow{2}{*}{$\begin{array}{l}\text { Parameters } \\
\text { Treatments }\end{array}$} & \multirow{2}{*}{$\begin{array}{c}\text { Number of } \\
\text { J2S / 250gm } \\
\text { soil }\end{array}$} & \multicolumn{3}{|c|}{ Nematode parameters /root system } \\
\hline & & Number of Galls & Number of Egg-masses & Number of Females \\
\hline Garlic $1 \%$ & $100 \mathrm{~d}$ & $78 \mathrm{~b}$ & $74.75 \mathrm{~b}$ & $66.5 \mathrm{bc}$ \\
\hline Garlic $2 \%$ & 74.25 ef & $63.25 \mathrm{~cd}$ & $59.75 \mathrm{c}$ & $58.25 \mathrm{~d}$ \\
\hline Garlic $3 \%$ & $54.25 \mathrm{~g}$ & $40.25 \mathrm{f}$ & $37.75 \mathrm{~d}$ & $33.75 \mathrm{e}$ \\
\hline lemon grass $1 \%$ & $135 \mathrm{~b}$ & $83.75 \mathrm{~b}$ & $77.25 \mathrm{~b}$ & $68 \mathrm{~b}$ \\
\hline Lemon grass $\mathbf{2} \%$ & $115.75 \mathrm{c}$ & $67.5 \mathrm{c}$ & $63.5 \mathrm{c}$ & $63.5 \mathrm{bcd}$ \\
\hline Lemon grass $\mathbf{3} \%$ & 77.5 ef & 56 de & $44.25 \mathrm{~d}$ & $37.5 \mathrm{e}$ \\
\hline Onion 1\% & $117.75 \mathrm{c}$ & $80.75 b$ & $76 b$ & $67.25 \mathrm{~b}$ \\
\hline Onion 2\% & $83.75 \mathrm{e}$ & $65.5 \mathrm{~cd}$ & $61 \mathrm{c}$ & $61 \mathrm{~cd}$ \\
\hline Onion 3\% & $65.75 \mathrm{fg}$ & $53.25 \mathrm{e}$ & $41 \mathrm{~d}$ & $35.75 \mathrm{e}$ \\
\hline Nematode alone & $180.25 \mathrm{a}$ & $165.5 \mathrm{a}$ & $154.25 \mathrm{a}$ & $163.5 \mathrm{a}$ \\
\hline Control & - & - & - & - \\
\hline
\end{tabular}

Table.2 Effect of garlic, onion and lemon grass on tomato plant growth parameters

\begin{tabular}{|l|c|c|c|c|c|}
\hline \multicolumn{1}{|c|}{$\begin{array}{c}\text { Parameters } \\
\text { Treatments }\end{array}$} & $\begin{array}{c}\text { Plant height } \\
(\mathbf{c m})\end{array}$ & $\begin{array}{c}\text { Root length } \\
(\mathbf{c m})\end{array}$ & $\begin{array}{c}\text { Fresh root } \\
\text { weight }(\mathbf{g})\end{array}$ & $\begin{array}{c}\text { Fresh shoot } \\
\text { weight }(\mathrm{g})\end{array}$ & $\begin{array}{c}\text { Dry shoot } \\
\text { weight }(\mathrm{g})\end{array}$ \\
\hline Garlic 1 \% & $50.75 \mathrm{bcd}$ & $15.00 \mathrm{abc}$ & $4.15 \mathrm{cde}$ & $20.55 \mathrm{bcd}$ & $2.97 \mathrm{~cd}$ \\
\hline Garlic 2\% & $52.75 \mathrm{abcd}$ & $12.12 \mathrm{c}$ & $4.55 \mathrm{bcd}$ & $22.25 \mathrm{abc}$ & $3.17 \mathrm{bcd}$ \\
\hline Garlic 3\% & $57.50 \mathrm{a}$ & $17.50 \mathrm{a}$ & $6.32 \mathrm{a}$ & $24.30 \mathrm{a}$ & $4.55 \mathrm{a}$ \\
\hline lemon grass 1\% & $39.87 \mathrm{e}$ & $12.87 \mathrm{bc}$ & $3.80 \mathrm{de}$ & $19.87 \mathrm{~cd}$ & $2.42 \mathrm{de}$ \\
\hline Lemon grass 2\% & $49.87 \mathrm{~cd}$ & $15.12 \mathrm{abc}$ & $4.17 \mathrm{cde}$ & $22.09 \mathrm{abc}$ & $2.65 \mathrm{de}$ \\
\hline Lemon grass 3\% & $53.50 \mathrm{abc}$ & $16.50 \mathrm{ab}$ & $4.90 \mathrm{bc}$ & $23.70 \mathrm{a}$ & $3.50 \mathrm{bc}$ \\
\hline Onion 1\% & $48.25 \mathrm{~d}$ & $13.75 \mathrm{abc}$ & $4.00 \mathrm{cde}$ & $20.31 \mathrm{~cd}$ & $2.60 \mathrm{de}$ \\
\hline Onion 2\% & $51.00 \mathrm{bcd}$ & $15.75 \mathrm{abc}$ & $4.27 \mathrm{cde}$ & $22.15 \mathrm{abc}$ & $2.95 \mathrm{~cd}$ \\
\hline Onion 3\% & $56.12 \mathrm{ab}$ & $17.25 \mathrm{a}$ & $5.17 \mathrm{~b}$ & $23.00 \mathrm{ab}$ & $3.90 \mathrm{ab}$ \\
\hline Nematode alone & $38.62 \mathrm{e}$ & $7.62 \mathrm{~d}$ & $2.92 \mathrm{f}$ & $10.28 \mathrm{e}$ & $1.85 \mathrm{e}$ \\
\hline Control & $42.00 \mathrm{e}$ & $12.25 \mathrm{c}$ & $3.35 \mathrm{ef}$ & $18.86 \mathrm{~d}$ & $1.87 \mathrm{e}$ \\
\hline
\end{tabular}

Columns followed by different letters are significantly different according to Duncan's Multiple Test $(\mathrm{P} \leq 0.05)$. 


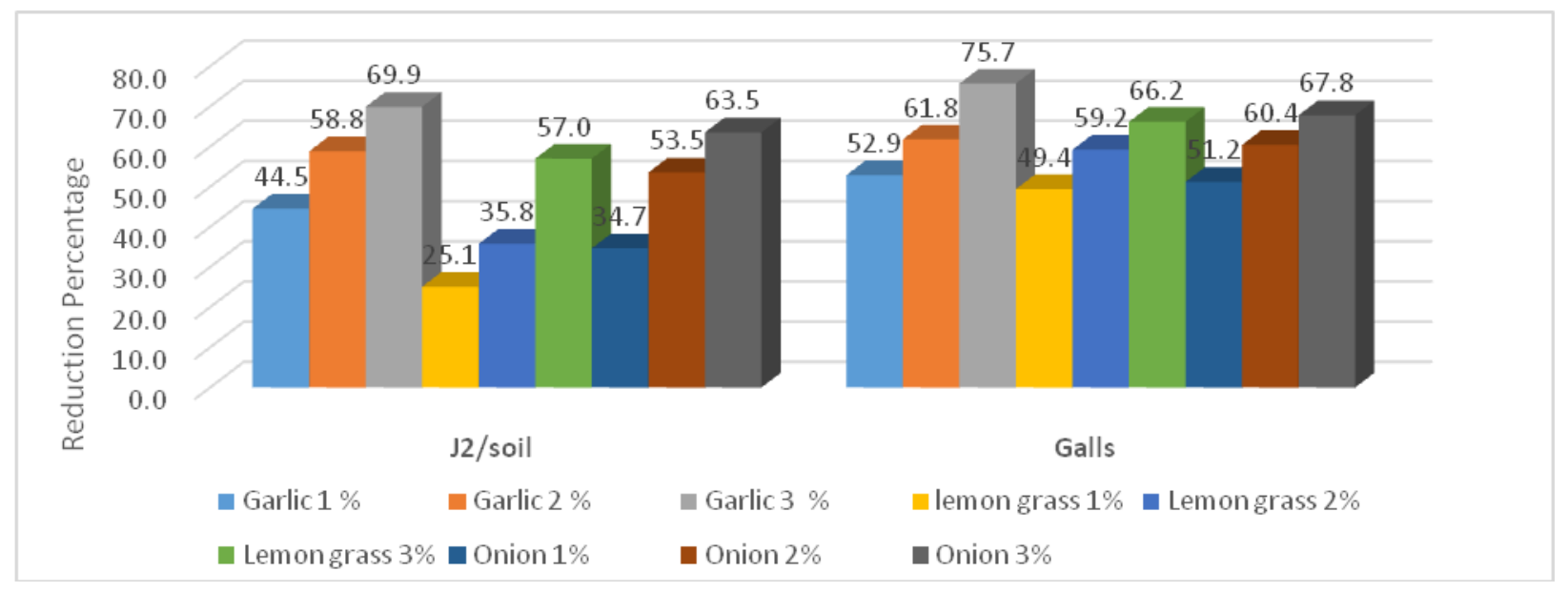

Fig.1 Effect of garlic, onion and lemon grass on Reduction Percentage of j2s/soil and galls /root system

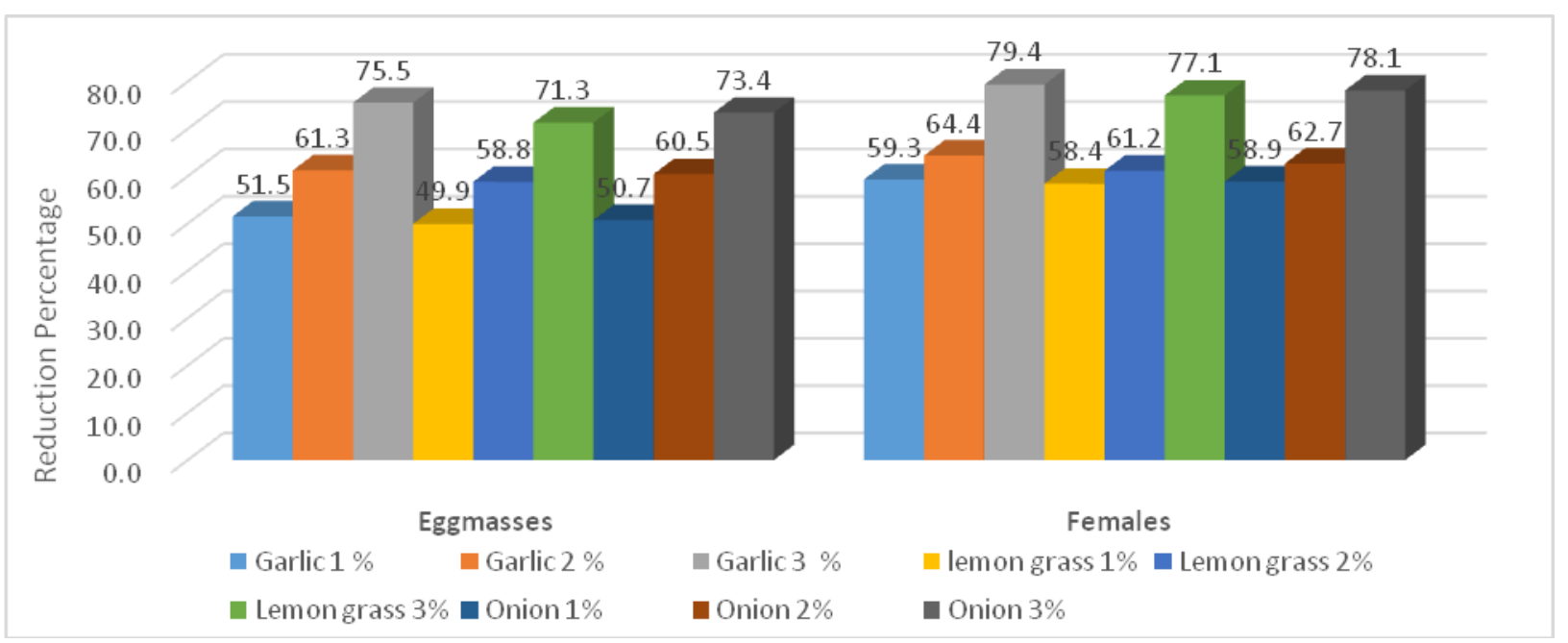

Fig.2 Effect of garlic, onion and lemon grass on reduction percentage of egg masses and females /root system

Decaying of plant materials in the soil, released compound may be act as nematicides. However, noticinga difference among treatments in their efficacy at different concentrations. This could be due to variance in chemical composition and toxic components concentration. Results showed that lower concentrations were less effective than higher concentration in all tested treatments. Garlic was effectively decreased number of $\mathrm{J} 2 \mathrm{~S}$ in pots soil, number of galls, egg masses and females /root system and increased fresh root and shoot weight and dry shoot weight of tomato plants. This result is similar to those by $[11,19]$ when using garlic plant extract or oil. The nematicidal effect of garlic may be due to richness in many component such as garlic oils that mainly 
consist of Allicina, diallylsulphide, allylmethyltrisulphidea, diallyldisulphidedi allytetrasulphidea, diallyltrisulphide, and allypropyldisulphidea which have a nematicidal activity $[20,21]$. A major members of garlic component is Allicin which have inhibitory effect against of $M$. incognita egg hatching [22]. Garlic may be have indirect effects on nematode populations by interrupt their mobility, food absorption and reproduction [23].

Results cleared that soil amendment with the leaves of lemon grass affect the nematode related parameters and enhanced plant growth parameter of tomato plants. This funding in agreement with those by previous researcher $[24,25]$ who showed nematicidal effect of lemon grass by reducing number eggs of $M$. javanica and $M$. incognita and root galling of tomato and African yam bean and inhibit egg hatching [26]. Lemon grass as a member of Cymbopogon genus produce essential oils rich in monoterpenes such as citral, citronellal, citronellol, elemol, linalool, limonene, 1,8cineole, geraniol, $\beta$-carophyllene, geranyl acetate, methyl heptenone and geranylformate [27]. Cymbopogon citratus contain aldehydecitral, geraniol and monoterpene olefins [28].

Allium cepa in the present study showed a nematicidal effect against root-knot nematode by reducing $\mathrm{J} 2 \mathrm{~S}$ in pot soil, number of galls, egg masses /root system. Similarly Goel and Gupta [29] reported the nematicidal potential of onion cv. N- 53 extract against second stage juveniles of $M$. javanica and Garvita Joshi et al., [30] reported the effect of onion in hatching and mortality of $M$. incognita.

Results confirmed the effectiveness of the botanicals in enhancing the plant growth parameters of tomato plants, which may be due to nutritional effect of the green manure and reduction in nematode by reducing $\mathrm{J} 2 \mathrm{~S}$, galls and egg masses. Reduction of plant growth in untreated plants may be due to its inability to use of water and nutrient from soil because of root injury, which became unable to uptake and translate water and nutrients. Plant growth phytohormons may be also affect by nematode infection [31]. Although present study recorded effective potential of the tested plants, may be this effect vary according to different factors such as: time of application, plant age, soil type, collection time $[4,8]$. Further studies must be on focus on combination of the tested plants as soil amendment with other different strategy. This will maximize the nematicidal activity and develop formulation to improve their efficacy and stability as an ecofriendly sustainable method for pant parasitic nematode management. These could lead to reduce using of synthetic nematicides and providing food security.

\section{References}

1. Abd-Elgawad, M.M., Yield losses by Phytonematodes: challenges and opportunities with special reference to Egypt. Egyptian Journal of Agronematology, 2014. 13(1): p. 75-94.

2. Bakr, R., M. Mahdy, and E. Mousa, A survey of root-knot and citrus nematodes in some new reclaimed lands in Egypt. Pakistan Journal of Nematology, 2011.29(2): p. 165-170.

3. Korayem, A., et al., A survey of plant parasitic Nematodes associated with different plants in North Sinai. Middle East Journal of Agriculture Research, 2014. 3(3): p. 522-529.

4. Bakr, R., et al., Efficacy of Nerium oleander Leaves extract on controlling Meloidogyne incognita in-Vitro and inVivo. Egyptian Journal of Crop Protection, 2015. 10(1): p. 1- 13.

5. Yudelman, M., A. Ratta, and D.F. Nygaard, Pest management and food 
production: looking to the future. Vol. 25. 1998: Intl Food Policy Res Inst.

6. Manju, P. and K. Sankari Meena, Antinemic properties of the botanicals. IJSN, 2015. 6(2): p. 125-134.

7. Javed, N., et al., Systemic and persistent effect of neem (Azadirachta indica) formulations against root-knot nematodes, Meloidogyne javanica and their storage life. Crop Protection, 2007. 26(7): p. 911-916.

8. Zasada, I., H. Ferris, and L. Zheng, Plant sources of Chinese herbal remedies: Laboratory efficacy, suppression of Meloidogyne javanica in soil, and phytotoxicity assays. Journal of nematology, 2002. 34(2): p. 124.

9. Oka, Y., Mechanisms of nematode suppression by organic soil amendments - a review. Applied Soil Ecology, 2010. 44(2): p. 101-115.

10. Bekhiet, M., et al., Effect of certain inorganic acids and garlic cloves oil for controlling the root-knot nematode Meloidogyne javanica infecting banana plant. Egypt. J. Agronematol, 2010. 9(2): p. 202-214.

11. El-Nagdi, W., M. Youssef, and M. Dawood, Efficacy of garlic clove and oil aqueous extracts against Meloidogyne incognita infecting eggplant. Pakistan Journal of Nematology, 2014. 32(2).

12. Hartman, K. and J. Sasser, Identification of Meloidogyne species on the basis of differential host test and perineal-pattern morphology. 1985.

13. Hussey, R. and K.R. Barker, A comparison of methods of collecting inocula of Meloidogyne spp., including a new technique. Plant Disease Reporter, 1973. 57: p. 1025-1028.

14. Daykin, M. and R. Hussey, Staining and histopathological techniques in nematology, in An advanced treatise on Meloidogyne, vol.II Methodology,, K.R.
Barker, C.C. Carter, and J.N. Sasser, Editors. 1985, north Carolina state University Graphics, Raleigh.: USA. p. 39-48.

15. Mahdy, M., Biological control of plant parasitic nematodes with antagonistic bacteria on different host plants. 2002, Universitäts-und Landesbibliothek Bonn.

16. Goody, J., Laboratory method for working with plant and soil nematodes. Ministry of Agric. Fisheries and food:. Technical bulletin, 1957. 2.

17. Kokalis-Burelle, N. and R. RodríguezKábana, Allelochemicals as biopesticides for management of plantparasitic nematodes, in Allelochemicals: biological control of plant pathogens and diseases. 2006, Springer. p. 15-29.

18. Anaya, A.L., Allelopathic organisms and molecules: Promising bioregulators for the control of plant diseases, weeds, and other pests, in Allelochemicals: biological control of plant pathogens and diseases. 2006, Springer. p. 31-78.

19. Terefe, M., Evaluation of nematicidal action of some bio-agents and botanicals for eco-friendly management of root-knot nematodes, Meloidogyne incognita on tomato. Science, Technology and Arts Research Journal, 2015. 4(3): p. 71-78.

20. Park, I.-K., et al., Nematicidal activity of plant essential oils and components from garlic (Allium sativum) and cinnamon (Cinnamomum verum) oils against the pine wood nematode (Bursaphelenchus xylophilus). Nematology, 2005. 7(5): p. 767-774.

21. Ibrahim, S.K., A. Traboulsi, and S. ElHaj, Effects of Essential Oils and Plant Extracts on Hatching, Migration and Mortality of Meloidogyne incognita. Phytopathologia Mediterranea, 2006. 45(3): p. 238-246. 
22. Gupta, R. and N. Sharmaj, A study of the nematicidal activity of allicin - an active principle in garlic, Allium sativum L., against root- knot nematode, Meloidogyne incognita (Kofoid and White, 1919) Chitwood, 1949. International Journal of Pest Management, 1993. 39(4): p. 390-392.

23. Block, E., Garlic and other alliums: the lore and the science. 2010: Royal society of Chemistry.

24. Lopes, E.A., et al., Soil amendment with chopped or ground dry leaves of six species of plants for the control of Meloidogyne javanica in tomato under greenhouse conditions. Ciência Rural, 2011. 41(6): p. 935-938.

25. Onyeke, C. and C. Akueshi, Infectivity and reproduction of Meloidogyne incognita (Kofoid and White) Chitwood on African yam bean, Sphenostylis stenocarpa (Hochst Ex. A. Rich) Harms accessions as influenced by botanical soil amendments. African Journal of Biotechnology, 2012. 11(67): p. 1309513103.

26. Pavaraj, M., G. Bakavathiappan, and S. Baskaran, Evaluation of some plant extracts for their nematicidal properties against root-knot nematode, Meloidogyne incognita. J. Biopest, 2012. 5: p. 106-110.
27. Ganjewala, D., RAPD characterization of three selected cultivars OD-19, GRL1 and Krishna of east indian lemongrass (Cymbopogon flexuosus Nees ex Steud) Wats. American-Eurasian Journal of Botany, 2008. 1(2): p. 53-57.

28. Dutta, D., et al., Qualities of lemongrass (Cymbopogan citratus) essential oil at different drying conditions. International Journal of Agriculture, Environment and Biotechnology, 2014. 7(4): p. 903.

29. Goel, S. and D. Gupta, Nematicidal properties of different plant parts of onion (Allium cepa) on the larval mortality of root-knot nematode (Meloidogynae javanica). Haryana Journal of Horticultural Sciences, 2004. 33: p. 291-293.

30. Garvita, J., B. Subhash, and M. Sharma, Effect of plant extracts on hatching and mortality of root-knot nematode, Meloidogyne incognita larvae (in-vitro). Indian Journal of Nematology, 2013. 43(2): p. 200-202.

31. Melakeberhan, H. and J.M. Webster, The phenology of plant-nematode interaction and yield loss, in Nematode interactions. 1993, Springer. p. 26-41.

\section{How to cite this article:}

Bakr, R.A. 2018. Bionematicidal Potential of Some Incorporating Plants on Meloidogyne javanica Control on Tomato. Int.J.Curr.Microbiol.App.Sci. 7(05): 1457-1464.

doi: https://doi.org/10.20546/ijcmas.2018.705.172 